\title{
PENGARUH 3 KECERDASAN AUDITOR TERHADAP KETEPATAN PEMBERIAN OPINI DENGAN PENGALAMAN SEBAGAI PEMODERASI
}

\author{
Yunita Kurnia Shanti 1, Susi Sih Kusumawardhani ${ }^{2}$ \\ Universitas Pamulang \\ email : kurniay25@gmail.com
}

\begin{abstract}
This study aims to examine the effect of 3 auditor intelligence, that is intellectual intelligence, emotional intelligence and spiritual intelligence on the accuracy of giving opinions with experience as a moderating at KAP in South Jakarta. The population in this study was the auditor at a public accounting firm in the South Jakarta area. The sampling method uses convenience sampling, based on the ease of access and availability of respondents. The number of samples 38 respondents from 5 KAP. The data analysis method uses simple linear regression and MRA.

The results of the research before being moderated showed that intellectual intelligence had a significant effect on the accuracy of giving opinions. emotional intelligence does not significantly influence the accuracy of opinion giving, spiritual intelligence significantly influences the accuracy of giving opinion. Then the results of research after moderation showed that intellectual intelligence is moderated by experience does not effect the accuracy of opinion giving, emotional intelligence is moderated by experience does not effect the accuracy of opinion giving, and Spiritual intelligence moderated by experience does not effect the accuracy of opinion giving. This shows that experience cannot strengthen the effect of auditor intelligence on the accuracy of opinion giving. This shows that the experience of an auditor is not necessarily able to strengthen the auditor's decision making, especially in terms of the accuracy of opinion giving.
\end{abstract}

Keywords: intellectual intelegence, emotional intelegence, spiritual intelegence experience, accuracy of giving opinions

\section{PENDAHULUAN}

Berbagai macam usaha untuk meningkatkan pendapatan untuk tetap bertahan dalam menghadapi persaingan tersebut terus dilakukan oleh para pelaku bisnis. Salah satu kebijakan yang ditempuh pihak perusahaan antara lain melakukan pemeriksaan laporan keuangan perusahaan oleh pihak ketiga yaitu akuntan publik. Laporan keuangan yang biasanya digunakan untuk mengetahui hasil usaha dan posisi keuangan perusahaan, juga dapat digunakan sebagai salah satu alat pertanggungjawaban pengelolaan manajemen perusahaan kepada pemilik. Dalam perkembangannya pihak-pihak luar perusahaan juga memerlukan informasi mengenai perusahaan untuk pengambilan keputusan yang berkaitan dengan penanaman modal (investasi) atau hal lain yang berhubungan dengan perusahaan.

Pemahaman yang baik terhadap peraturan yang berlaku, standar audit dan kode etik auditor diharapkan mampu menghasilkan laporan audit yang tepat. Laporan audit inilah yang digunakan auditor untuk menyampaikan pernyataan atau pendapatnya kepada para pemakai laporan keuangan sehingga bisa dijadikan acuan bagi para pemakai laporan keuangan tersebut. Opini audit merupakan final report atas audit yang dilakukan. Dengan pemberian opini oleh auditor sesuai kode etik yang berlaku, membawa dampak positif bagi masyarakat dan dunia usaha. Dalam memberikan opini yang tepat, ada beberapa hal yang bisa dilakukan auditor untuk dapat memberikan opini yang nantinya berguna dan dapat dipertanggungjawabkan kewajarannya. 
Berbagai macam usaha untuk meningkatkan pendapatan untuk tetap bertahan dalam menghadapi persaingan tersebut terus dilakukan oleh para pelaku bisnis. Salah satu kebijakan yang ditempuh pihak perusahaan antara lain melakukan pemeriksaan laporan keuangan perusahaan oleh pihak ketiga yaitu akuntan publik. Laporan keuangan yang biasanya digunakan untuk mengetahui hasil usaha dan posisi keuangan perusahaan, juga dapat digunakan sebagai salah satu alat pertanggungjawaban pengelolaan manajemen perusahaan kepada pemilik. Dalam perkembangannya pihak-pihak luar perusahaan juga memerlukan informasi mengenai perusahaan untuk pengambilan keputusan yang berkaitan dengan penanaman modal (investasi) atau hal lain yang berhubungan dengan perusahaan.

Pemahaman peraturan, kode etik dan standar audit menjadi kewajiban auditor dalam menghasilkan laporan audit yang baik, hal ini mendukung auditor dalam pemberian opini audit yang tepat. Opini audit yang tepat sangat dibutuhkan oleh pembuat keputusan dalam dunia usaha. Laporan audit inilah yang digunakan auditor untuk menyampaikan pernyataan atau pendapatnya kepada para pemakai laporan keuangan sehingga bisa dijadikan acuan bagi para pemakai laporan keuangan tersebut. Opini audit merupakan final report atas audit yang dilakukan atas laporan keuangan yang di audit. Dengan pemberian opini oleh auditor sesuai posedur dan kode etik yang berlaku, membawa citra positif bagi masyarakat dan dunia usaha. Beberapa faktor dapat menentukan ketepatan pemberian opini audit. Kecerdasan Intelektual merupakan kemampuan seseorang dalam membaca, memahami, dan menginterprestasikan setiap informasi khususnya yang berkaitan dengan pelajaran yang diterimanya. Selain itu kecerdasan emosional seorang auditor diperlukan untuk membantu auditor dalam melakukan pemeriksaan guna mendeteksi kebenaran atas laporan keuangan yang disajikan klien. Berikutnya auditor mempunyai kecerdasan spiritual yang tepat, skandal dan manipulasi tindakan yang dilakukan oleh auditor tidak dapat terjadi. Secara singkat kecerdasan spiritual mampu mengintegrasikan dua kemampuan lain yang sebelumnya sudah disebutkan yaitu kecerdasan intelektual dan kecerdasan emosional, Choirah (2013). Banyaknya penugasan audit yang dilaksanakan akan menambah pengalaman kerja auditor, ditambah dengan masa kerja sebagai auditor dan berbagai jenis klien yang pernah diaudit. Diharapkan dengan semakin berpengalaman seorang auditor akan mendukung ketepatan pemberian opini audit. Dalam penelitian ini menguji pengaruh 3 kecerdasan auditor terhadap ketepatan pemberian opini dengan pengalaman sebagai pemoderasi.

\section{TINJAUAN PUSTAKA}

Arens, Beasley, dan Elder (2010:24) berpendapat bahwa auditing adalah suatu proses yang sistematis untuk mendapatkan dan mengevaluasi bukti - bukti dari suatu informasi atau asersi management tertentu, yang akan digunakan untuk menetapkan dan melaporkan tingkat kesesuaian antara informasi atau asersi management tersebut dengan kriteria yang telah ditetapkan. Proses ini dilakukan oleh orang yang kompeten dan independen. Standar Auditing berbeda dengan prosedur auditing. "Prosedur" berkaitan dengan tindakan yang harus dilaksanakan, sedangkan "Standar" berkenaan dengan kriteria atau ukuran mutu kinerja tindakan tersebut dan berkaitan dengan tujuan yang hendak dicapai melalui penggunaan prosedur tersebut (PSA No.1, Standar Audit Seksi 150). Dengan demikian standar audit mencakup mutu profesional (professional qualities) auditor independen dan pertimbangan (judgment) yang digunakan dalam pelaksanaan audit dan penyusunan laporan keuangan.

Standar auditing merupakan panduan umum bagi auditor dalam memenuhi tanggung jawab profesinya untuk melakukan audit atas laporan keuangan historis. Standar ini mencakup pula pertimbangan kualitas profesional seperti kompetensi dan independensi, persyaratan pelaporan serta bukti audit. Standar audit yang telah ditetapkan dan disahkan oleh Ikatan Akuntan Indonesia pada tahun 2001 terdiri dari sepuluh standar yang dikelompokkan menjadi tiga kelompok besar, yaitu standar umum, standar pekerjaan lapangan dan standar pelaporan. Jenis-Jenis Auditor Menurut Hery (2017:2) Auditor dapat dibedakan menjadi empat jenis, yaitu Auditor Pemerintah, Auditor Forensik, Auditor Internal, Auditor Eksternal 


\section{Kecerdasan Intelektual}

Kecerdasan Intelektual merupakan kemampuan seseorang dalam membaca, memahami, dan menginterprestasikan setiap informasi khususnya yang berkaitan dengan pelajaran yang diterimanya. Jika Seorang auditor tanpa memiliki kecerdasan intelektual yang baik ia tidak akan mampu memahami dan mengaplikasikan pengetahuan yang ia peroleh baik dalam bidang akuntansi maupun auditing di dalam melaksanakan tugasnya. Sehingga auditor tidak dapat melakukan pemeriksaan/audit dengan baik, dimana hasil pemeriksaan tersebut akan menjadi tolak ukur auditor dalam menentukan atau mengambil keputusan dalam pemberian opini audit. Hal ini menunjukkan bahwa kecerdasan intelektual dapat mendukung ketepatan pemberian opini audit yang diberikan oleh seorang auditor.

\section{Kecerdasan Emosional}

Kecerdasan emosional mengacu pada kemampuan seseorang untuk merefleksikan emosi seseorang dan suasana hati dan berhasil mengelolanya. Semakin kompleks pekerjaan, makin penting kecerdasan emosional. Emosi yang lepas kendali dapat membuat seseorang yang pandai menjadi bodoh. Sebagai seorang auditor kecerdasan emosional diperlukan untuk membantu auditor dalam melakukan pemeriksaan guna mendeteksi kebenaran atas laporan keuangan yang disajikan klien. Kecerdasan emosional akan mempermudah seorang auditor untuk melakukan pemeriksaan, memiliki motivasi yang kuat, mengontrol diri atau emosi, rasa empati serta keterampilan dalam bersosialisasi akan membantu auditor dalam menelusuri bukti-bukti audit serta informasi terkait.

\section{Kecerdasan Spiritual}

Kecerdasan spiritual adalah sikap moral yang dipandang luhur oleh seseorang. Seseorang yang mempunyai kecerdasan spiritual yang tinggi akan mampu bertindak atau berperilaku dengan etis dalam profesinya dan organisasi. Apabila seorang auditor tidak memiliki kemampuan spiritual yang tinggi, maka seorang auditor tersebut bisa saja melakukan hal yang menyimpang misalnya saja tidak jujur. Kecerdasan spiritual yang juga berpengaruh terhadap ketepatan pemberian opini auditor, apabila auditor mempunyai kecerdasan spiritual yang tepat, skandal dan manipulasi tindakan yang dilakukan oleh auditor tidak dapat terjadi. Secara singkat kecerdasan spiritual mampu mengintegrasikan dua kemampuan lain yang sebelumnya sudah disebutkan yaitu kecerdasan intelektual dan kecerdasan emosional, Choirah (2013).

\section{Pengalaman Auditor}

Pengalaman yang mengajarkan auditor agar lebih mudah mengumpulkan bukti- bukti secara objektif dari laporan keuangan yang akan diaudit. Pengalaman menjadi salah satu faktor yang mempengaruhi ketepatan pemberian opini audit. Pengalaman yang dimaksudkan disini adalah pengalaman auditor dalam melakukan pemeriksaan laporan keuangan baik dari segi lamanya waktu atau banyaknya penugasan yang pernah dilakukan. Menurut Adrian (2013) seorang auditor yang berpengalaman akan memberikan opini lebih tepat dibandingkan dengan auditor yang kurang berpengalaman, karena auditor yang berpengalaman memiliki pemahaman dan pengetahuan yang lebih baik.

\section{Opini Audit}

Setelah selesai melakukan audit secara sistematis auditor independen menyiapkan laporan hasil audit dengan mengkomunikasikan kesimpulan yang diperoleh dan menyusun rekomendasi mengenai laporan keuangan yang diaudit. Selanjutnya auditor menyatakan pendapatnya (opini) didalam laporan hasil audit untuk disampaikan kepada para pemakai laporan keuangan. Opini audit merupakan hasil akhir auditor dalam melakukan audit laporan keuangan Menurut Halim (2008) dalam Lisnawati (2014) laporan yang paling banyak dikeluarkan oleh auditor adalah laporan bentuk baku. Laporan bentuk baku memuat pernyataan pendapat auditor independen mengenai kewajaran laporan keuangan yang disajikan klien sesuai dengan prinsip akuntansi yang berlaku umum. Terdapat lima jenis pendapat yang dapat diberikan oleh auditor, yaitu (1) Pendapat wajar tanpa 
pengecualian, (2) Pendapat wajar tanpa pengecualian dengan tambahan bahasa penjelasan, (3) Pendapat wajar dengan pengecualian, (4) Pendapat tidak wajar, (5) Pernyataan tidak memberikan pendapat.

\section{KERANGKA PEMIKIRAN}

Menurut Umar Sekaran (2016:60) Kerangka berpikir merupakan model konseptual tentang bagaimana teori berhubungan dengan berbagai faktor yang telah diidentifikasi sebagai hal yang penting. Dalam penelitian ini hipotesa yang disusun yaitu H1: Diduga Kecerdasan intelektual berpengaruh secara signifikan terhadap ketepatan auditor dalam pemberian opini, H2: Diduga Kecerdasan emosional berpengaruh secara signifikan terhadap ketepatan auditor dalam pemberian opini, H3: Diduga Kecerdasan spiritual berpengaruh secara signifikan terhadap ketepatan auditor dalam pemberian opini, Pengaruh Kecerdasan intelektual terhadap ketepatan auditor dalam pemberian opini dengan pengalaman auditor sebagai pemoderasi, H4: Kecerdasan intelektual berpengaruh signifikan terhadap ketepatan auditor dalam pemberian opini dengan pengalaman auditor sebagai pemoderasi, H5:Kecerdasan emosional berpengaruh signifikan terhadap ketepatan auditor dalam pemberian opini dengan pengalaman auditor sebagai pemoderasi, H6: Kecerdasan emosional berpengaruh signifikan terhadap ketepatan auditor dalam pemberian opini dengan pengalaman auditor sebagai pemoderasi.

\section{METODE}

\section{Tehnik Pengumpulan Data}

Tehnik pengumpulan data dalam penelitian ini menggunakan metode field research atau penelitian lapangan dengan cara peneliti memperoleh data langsung dari pihak pertama (data primer). Pada penelitian ini, yang menjadi subyek penelitian adalah auditor eksternal yang bekerja pada kantor akuntan publik di Jakarta Selatan. Peneliti memperoleh data dengan menyampaikan kuesioner kepada kantor akuntan publik secara langsung ataupun melalui perantara. Setelah kuesioner diisi dan dikembalikan, lalu data diolah menggunakan program SPSS.

Populasi dalam penelitian ini adalah akuntan publik atau auditor eksternal yang bekerja di KAP wilayah Jakarta Selatan. Menurut Sugiyono (2013:117) sampel adalah bagian dari jumlah dan karakteristik yang dimiliki oleh populasi tersebut. Metode penentuan sampel dengan menggunakan convenience sampling. Hal ini didasari oleh akses kemudahan jarak wilayah tersebut dijangkau oleh peneliti dan ketersediaan responden. Jumlah sampel yang diperoleh sebanyak 5 KAP di wilayah Jakarta Selatan dengan 41 auditor sebagai responden, sebanyak 39 kuesioner kembali dan hanya 38 kuesioner yang bisa diolah.

\section{Sumber data}

Data yang digunakan dalam penelitian ini berupa data primer. Menurut Sugiyono (2016: 46) Angket atau kuesioner merupakan pengumpulan data yang dilakukan dengan cara memberi seperangkat pertanyaan atau pernyataan tertulis kepada responden untuk dijawab dengan menggunkan skala likert. Skala likert adalah skala yang digunakan untuk mengukur sikap, pendapat dan persepsi seseorang atau sekelompok orang tentang fenomena sosial (Sugiyono, 2016: 47). Semua variabel diukur dengan menggunakan skala likert 5 poin dari sangat tidak setuju (1), tidak setuju (2), netral (3), setuju (4) sangat setuju (5) menurut penelitian Silvia Hellena, 2015.

\section{Variabel dan Pengukuran}

Varibel-variabel dalam penelitian ini diklasifikasikan menjadi 3 yaitu variabel dependen, variabel independen dan variabel pemoderasi. Variabel tersebut antara lain;

1. Variabel Kecerdasan intelektual adalah kemampuan intelektual, analisa, logika, dan rasio. Kecerdasan ini merupakan kecerdasan untuk menerima, menyimpan, dan mengolah informasi menjadi fakta (Widodo, 2012:77). Kecerdasan intelektual merupakan kemampuan untuk mengorganisasikan pola-pola tingkah laku seseorang sehingga dapat bertindak lebih 
efektif dan lebih tepat dalam situasi-situasi baru yang berubah-ubah. Indikator varibel ini diukur dengan pembawaan, kematangan, pembentukan diri, minat, dan kebebasan

2. Kecerdasan emosional dapat membantu membangun hubungan dalam menuju kebahagiaan dan kesejahteraan. Rachmi (2010) mendefinisikan kecerdasan emosional sebagai komponen yang membuat seseorang menjadi pintar menggunakan emosinya. Emosi manusia berada di wilayah dari perasaan lubuk hati, naluri yang tersembunyi dan sensasi emosi yang apabila diakui dan dihormati, kecerdasan emosional akan menyediakan pemahaman yang lebih mendalam dan lebih utuh tentang diri sendiri dan orang lain. Indikator variabel ini diukur dengan mengenali emosi diri, mengelola emosi, motivasi diri, mengenal emosi orang lain, dan membina hubungan dengan orang lain

3. Kecerdasan spiritual adalah kecerdasan untuk menghadapi dan memecahkan persoalan makna dan nilai yang lebih luas dan kaya, kecerdasan untuk menilai bahwa tindakan atau jalan hidup seseorang lebih bermakna dibandingkan orang lain (Zohar dan Marshall,2007:4) Kecerdasan spiritual sebagai rasa moral, kemampuan menyesuaikan aturan yang kaku dibarengi dengan pemahaman dan cinta serta kemampuan setara untuk melihat kapan cinta dan pemahaman sampai pada batasnya, juga memungkinkan kita bergulat dengan ihwal baik dan jahat, membayangkan yang belum terjadi serta mengangkat kita dari kerendahan. Variabel ini diukur dengan pernyataan yang berkaitan dengan kecerdasan spiritual. Indikator variabel ini diukur dengan kemampuan bersikap fleksibel, tingkat kesadaran yang tinggi, kemampuan menghadapi dan memanfaatkan penderitaan sebagai motivasi.

4. Pengalaman auditor dapat diperoleh dari lamanya bekerja dan banyaknya tugas atau pemeriksaan yang dilakukan auditor. Semakin lama auditor bekerja dengan cara melakukan tugas auditnya berulang- ulang maka akan menambah pengalaman auditnya. Indikator variable pengalaman auditor yang digunakan dalam penelitian ini adalah Lamanya waktu bekerja, Banyaknya penugasan audit, Banyaknya Jenis perusahaan yang diaudit

5. Ketepatan pemberian opini auditor sangat dibutuhkan oleh kalangan usaha, maka mendorong auditor untuk memahami pelaksanaan etika yang berlaku dalam menjalankan profesi untuk menghasilkan laporan audit yang tepat. Laporan audit inilah yang digunakan auditor untuk menyampaikan pernyataan atau pendapatnya kepada para pemakai laporan keuangan sehingga bisa dijadikan acuan bagi para pemakai laporan keuangan tersebut. Ketepatan pemberian opini auditor ini diukur dengan pertanyaan yang berkaitan dengan pengetahuan dan ruang lingkup audit. Indikator variabel ini diukur dengan memiliki pengetahuan tentang standar audit, pengetahuan tentang PSAK, pengetahuan tentang Opini Audit, dan pembatasan dalam ruang lingkup audit.

\section{Tehnik Analisis Data}

Tehnik analisis data yang digunakan meliputi statistik diskriptif (Ghozali; 2013:19) uji deskriptif memberikan gambaran atau deskripsi suatu data yang dilihat dari nilai rata-rata (mean), standar deviasi, maksimum dan minimum. Untuk menguji kualitas data kuisioner peneliti menggunakan uji validitas dan reliabilitas, yang mana memastikan valid tidaknya suatu kuisioner dan handal konsisten dari suatu pernyataan. Uji asumsi klasik merupakan pengujian asumsi-asumsi statistik yang harus dipenuhi pada analisis regresi linier sederhana meliputi uji normalitas, uji heterokedasitas dan uji multikolonieritas. Pengujian hipotesis dengan analisis regresi linear sederhana dan MRA (multiple regresi analisyst). Regresi linear sederhana untuk menguji pengaruh self efficacy terhadap audit judgement, dan MRA digunakan untuk menguji pengaruh self efficacy terhadap audit judgement dengan dimoderasi senioritas auditor dengan bantuan program komputer SPSS 22. Persamaan yang dibentuk adalah sebagai berikut :

$\mathbf{Y}=\alpha+\beta X 1+\beta X 2+\beta X 3+\beta X 1 * Z+\beta X 2 * Z+\beta X 3 * Z+e$ 
Pengujian yang dilakukan adalah sebagai berikut :

a. Uji kualitas data yaitu validitas dan reliabilitas

b. Uji statistik dekriptif

c. Uji asumsi klasik yaitu normalitas, heterokedasitas dan multikoloniaritas

d. Uji koefisien determinasi

e. Uji regresi sederhana

f. Uji MRA

\section{HASIL DAN PEMBAHASAN}

\section{Isi Hasil dan Pembahasan}

Berikut ini akan dijelaskan hasil dan pembahasan penelitian sesuai tehnik analisa data yang digunakan oleh peneliti. Objek dalam penelitian ini adalah auditor yang bekerja pada Kantor Akuntan Publik di wilayah Jakarta Selatan sebanyak 5 KAP dengan 41 responden yang mengisi kuesioner. Sebanyak 40 kuesioner kembali dan hanya 38 kuesioner yang bisa diolah. Jumlah sampel yang didapat berjumlah 38 sampel data dengan jumlah pria sebanyak 23 responden dengan presentase sebesar 60\% sedangkan responden wanita sebanyak 15 responden dengan presentase sebesar $40 \%$.

Jabatan para responden yang ada dalam 5 KAP tersebut sebanyak 4 responden sebagai manager sebesar 10\%, 15 responden supervisi sebesar 40\%, 11 responden auditor senior sebesar 30\% dan 8 responden auditor junior sebesar 20\%. Selanjutnya peneliti akan menguraikan lama bekerja semua reponden dalam KAP tersebut, sebanyak 11 responden mempunyai masa kerja kurang dari satu tahun sebesar 30\%, sebanyak 10 responden dengan masa kerja 1-3 tahun, sebesar 25\%, sebanyak 11 responden dengan masa kerja 3-5 tahun sebesar 30\% dan sisanya sebanyak 6 responden dengan masa kerja diatas 5 tahun sebesar $15 \%$.

\subsection{Uji Kualitas Data}

4.1.2 Uji Validitas

Berdasarkan hasil uji validitas pada variable moderasi pengalaman auditor memiliki pearson correlation dari $0,3683-0.9944$. Variable independen yaitu kecerdasan intelektual memperoleh pearson correlation dari 0,3233 - 0,7195, sedangkan kecerdasan emosional memiliki pearson correlation dari 0,6287 - 0,8870, dan kecerdasan spiritual memiliki pearson correlation dari $0,3611-0,6442$. Dan variable dependen ketepatan pemberian opini audit memperoleh pearson correlation dari 0,3219 - 0,6419. Seluruh variable bebas, vaiabel moderasi dan variable terikat menunukkan hasil pearson correlation lebih besar dari 0,3 yang berarti bahwa peryataan-pernyataan dalam kuesioner tersebut valid.

\subsubsection{Uji Reliabilitas}

Hasil uji reliabilitas pada variable moderasi pengalaman auditor menujukkan koefisien cronbach's alpha 0.897. pada variable indepeden kecerdasan intelektual menunjukkan koefisien cronbach's alpha 0.761, kecerdasan emosional menujukkan koefisien cronbach's alpha 0,933, kecerdasan spiritual menujukkan koefisien cronbach's 0,601. Dan untuk variable dependen Ketepatan pemberian opini menjunjukkan koefisien Cronbach's alpha 0.668. Seluruh hasil koefisien cronbach's alpha pada variable moderasi, variable bebas dan variable terikat menunjukkan lebih dari 0,6 sehingga dikatakan seluruh pernyataan-pernyataan dalam kuestioner tersebut reliabel. 


\subsection{Statistik Deskriptif}

\section{Descriptive Statistics}

\begin{tabular}{|l|r|r|r|r|r|}
\hline & \multicolumn{1}{|c|}{ N } & Minimum & Maximum & \multicolumn{1}{c|}{ Mean } & Std. Deviation \\
\hline Kecerdasan Intelektual & 38 & 28,0 & 50,0 & 40,868 & 6,2219 \\
Kecerdasan Emosional & 38 & 15,0 & 50,0 & 37,342 & 10,0654 \\
Kecerdasan Spiritual & 38 & 31,0 & 49,0 & 41,789 & 4,6041 \\
Pengalaman Auditor & 38 & 40,0 & 50,0 & 46,605 & 4,2841 \\
Opini & 38 & 33,0 & 50,0 & 43,632 & 4,3085 \\
Valid N (listwise) & 38 & & & & \\
\hline
\end{tabular}

Pada table 1 menunjukkan hasil analisis dengan menggunakan statistik deskriptif terhadap variabel pengalaman Auditor menunjukan nilai minimum sebesar 40, nilai maksimum sebesar 50, nilai rata-rata sebesar 46,09 dengan standar deviasi 4,2841. Selain itu, variabel kecerdasan intelektual dengan nilai minmum sebesar 28 , nilai maksimum 50, nilai rata-rata sebesar 40,868 dengan standar deviasi sebesar 6,2219, variabel kecerdasan emosional dengan nilai minimum sebesar 15 , nilai maksimum 50, nilai rata-rata sebesar 37,342 dengan standar deviasi sebesar 10,065, variabel kecerdasan spiritual dengan nilai minmum sebesar 31 , nilai maksimum 49, nilai rata-rata sebesar 41,789 dengan standar deviasi sebesar 4,6041. Dan untuk hasil variabel dependen yaitu ketepatan pemberian opini dengan nilai minimum 33, nilai maksimum sebesar 50, nilai rata-rata 43,632 dengan standar deviasi sebesar 4,3085.

\subsection{Uji Asumsi Klasik}

Uji Asumsi klasik dilakukan guna mengetahui layak atau tidaknya suatu data dalam penelitian untuk dianalisis, uji asumsi klasik ini bertujuan untuk memberikan kepastian bahwa persamaan regresi yang didapatkan memiliki ketepatan dalam estimasi, tidak bias dan konsisten. Uji asumsi klasik yang digunakan dalam penelitian ini antara lain Uji Normalitas, Uji Multikolonieritas, dan Uji Heterokedastisitas.

\subsubsection{Uji Normalitas}

Uji Normalitas dilakukan dengan tujuan untuk menguji apakah dalam model regresi, variabel pengganggu atau residual memiliki distribusi normal (Ghozali, 2013:154). Jika terdapat normalitas, maka residual akan terdistribusi secara normal dan independen, medel regresi yang baik adalah yang memilikai distribusi data normal atau mendekati normal. Dalam penelitian ini, uji normalitas dilakukan menggunakan metode Non-Parametic Kolmogorov Smirnov $(K-S)$. 
One-Sample Kolmogorov-Smirnov Test

\begin{tabular}{|ll|r|}
\hline & & $\begin{array}{r}\text { Unstandardiz } \\
\text { ed Residual }\end{array}$ \\
\hline Normal Parameters & a,b & Mean \\
& Std. Deviation & 1,34858643 \\
Most Extreme Differences & Absolute &, 120 \\
& Positive &, 120 \\
Test Statistic & Negative &,- 095 \\
Asymp. Sig. (2-tailed) & &, 120 \\
\hline
\end{tabular}

a. Test distribution is Normal.

b. Calculated from data.

c. Lilliefors Significance Correction.

Pada table 2 menunjukkan hasil metode uji Kolomogorov-Smirnov (K-S) dengan melihat nilai probabilitas dignifikansi data residual, jika angka probabilitasnya kurang dari 0,05 maka variabel ini berdistribusi secara tidak normal. Sebaliknya, jika propabilitas diatas nilai 0,05 maka data dapat dikatan telah berdistribusi secara normal. Hasil uji Kolomogorov-Smirnov $(K-S)$ menunjukkan bahwa nilai Asymp. Sig (2-Tailed) sebesar 0,184 yang berarti lebih besar dibanding dengan 0,05 sehingga model penelitian ini telah memenuhi uji asumsi klasik normalitas.

\subsubsection{Uji Multikolinieritas}

Uji Multikolinieritas bertujuan untuk menguji apakah model regresi ditemukan adanya korelasi antara variabel bebas (independen) dalam model regresi (Ghozali, 2013:103). Model regresi dikatakan baik apabila tidak terjadi korelasi antar variabel independen. Untuk menditeksi adanya msalah Multikolinieritas dalam penelitian ini menggunakan Tolerance Value atau Nilai Toleransi dan Variance Infaction Factor $(V I F)$. Regresi yang terbebas dari masalah Multikolinieritas yaitu apabila VIF $<10$ dan Tolerance $>0,1$, maka data tersebut tidak ada masalah Multikolinieritas.

Coefficients $^{a}$

\begin{tabular}{|ll|r|r|}
\hline \multirow{2}{*}{ Model } & \multicolumn{2}{|c|}{ Collinearity Statistics } \\
\cline { 3 - 4 } & & Tolerance & \multicolumn{1}{c|}{ VIF } \\
\hline 1 & Kecerdasan Intelektual &, 367 & 2,724 \\
& Kecerdasan Emosional &, 836 & 1,196 \\
& Kecerdasan Spiritual &, 353 & 2,831 \\
& Pengalaman Auditor &, 970 & 1,030 \\
\hline
\end{tabular}

a. Dependent Variable: Opini

Berdasarkan Tabel 4.3 diatas dapat diketahui bahwa data dalam penelitian ini tidak terdapat multikolinieritas. Hal ini dapat dibuktikan dari hasil nilai Tolerance yang lebih besar dari 0,1 dengan nilai pada variabel pengalaman auditor sebesar 0,970 dan nilai variabel kecerdasan intelektual sebesar 0,367, nilai pada variabel kecerdasan emosional 0,836, dan nilai pada variabel kecerdasan spiritual 0,353 . Selain itu pembuktian lewat nilai VIF yang lebih kecil dari 10 dengan nilai variabel pengalaman auditor sebesar 1,030, 
nilai variabel kecerdasan intelektual sebesar 2,724, nilai variabel kecerdasan emosional 1,196, dan nilai variabel kecerdasan spiritual 2,831. ini membuktikan bahwa semua variabel independen dan variable moderasi tidak terjadi masalah multikolonieritas karena masing-masing variabel memiliki nilai tolerance lebih besar dari 0,1 dan nilai VIF lebih kecil dari 10.

\subsubsection{Uji Heterokedasitas}

Untuk mengetahui ada atau tidaknya heteroskedastisitas, dalam penelitian ini dilakukan uji statistik dengan menggunakan Uji Glejser. Dimana akan dikatakan terbebas dari heteroskedasitas apabila nilai signfikansinya diatas $5 \%$ (sig > 0,05$)$.

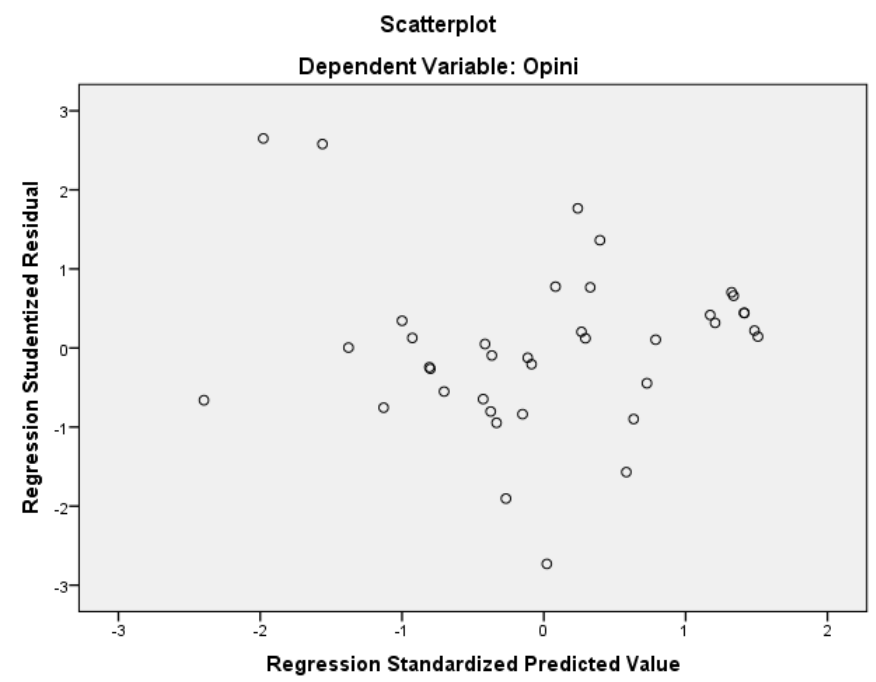

Hasil Uji Heteroskedastisitas dengan menggunakan Uji Scatterplot dapat dilihat pada Tabel $4.4 \mathrm{~d}$ Dari hasil uji di atas terlihat bahwa titik-titik menyebar secara acak serta menyebar tidak membentuk pola tertentu dan tersebar di atas dan di bawah angka 0 pada sumbu Y. hal ini membuktikan bahwa tidak terjadi heterokedastistas pada model regresi ini.

\subsection{Uji Hipotesa Sebelum MRA}

\subsubsection{Uji Koefisien Determinasi}

Koefesien Derteminan $\left(\mathrm{R}^{2}\right)$ pada intinya mengukur seberapa jauh kemampuan model regresi dalam menerangkan pengaruh variabel independen terhadap variabel dependen. Dalam penelitian ini menggunakan variabel independen 3 kecerdasan auditor dengan variabel dependen ketepatan pembeian opini audit.

\section{Model Summary}

\begin{tabular}{|l|c|r|r|r|r|}
\hline Model & $\mathrm{R}$ & R Square & $\begin{array}{c}\text { Adjusted R } \\
\text { Square }\end{array}$ & $\begin{array}{c}\text { Std. Error of } \\
\text { the Estimate }\end{array}$ & $\begin{array}{c}\text { Durbin- } \\
\text { Watson }\end{array}$ \\
\hline 1 &, $950^{\mathrm{a}}$ &, 902 &, 890 & 1,4280 & 2,044 \\
\hline
\end{tabular}

a. Predictors: (Constant), Pengalaman Auditor, Kecerdasan Spiritual, Kecerdasan Emosional, Kecerdasan Intelektual

\section{b. Dependent Variable: Opini}

Pada tabel 4.4 Uji Koefesien Determinan bisa kita lihat nilai Adjust $R$ Square sebesar 0,89 atau dalam presentase sebesar $89 \%$ variabel ketepatan pemberian opini dapat dijelaskan atau dipengauhi oleh variabel 3 kecerdasan auditor. Sedangkan sisanya sebesar 11\% dijelaskan oleh faktor-faktor lain yang tidak termasuk dalam analisa regresi pada penelitian ini. 
Coefficients $^{\mathrm{a}}$

\begin{tabular}{|c|c|c|c|c|c|c|c|c|}
\hline \multirow[b]{2}{*}{ Mode } & & \multicolumn{2}{|c|}{ Unstandardized Coefficients } & \multirow{2}{*}{$\begin{array}{c}\text { Standardized } \\
\text { Coefficients } \\
\text { Beta }\end{array}$} & \multirow[b]{2}{*}{$t$} & \multirow[b]{2}{*}{ Sig. } & \multicolumn{2}{|c|}{ Collinearity Statistics } \\
\hline & & $B$ & Std. Error & & & & Tolerance & VIF \\
\hline \multirow[t]{5}{*}{1} & (Constant) & 11,496 & 3,440 & & 3,342 &, 002 & & \\
\hline & Kecerdasan Intelektual &, 186 &, 062 &, 269 & 2,994 &, 005 &, 367 & 2,724 \\
\hline & Kecerdasan Emosional &,- 028 &, 026 &,- 066 & $-1,107$ & .276 &, 836 & 1,196 \\
\hline & Kecerdasan Spiritual &, 685 &, 086 &, 733 & 7,990 &, 000 &, 353 & 2,831 \\
\hline & Pengalaman Auditor &,- 066 &, 056 &,- 066 & $-1,187$ & 244 & 970 & 1,030 \\
\hline
\end{tabular}

a. Dependent Variable: Opini

Dalam penelitian ini dilakukan analisisi regresi linier berganda untuk mengetahui ada atau tidaknya pengaruh variabel bebas (independen) terhadap variabel terikat (dependen). Variabel kecerdasan intelektual ditentukan dengan melihat nilai signifikansi di tabel Coefficients yaitu dengan nilai 0,005 lebih kecil dibanding dengan 0,05 ini berarti kecerdasan intelektual berpengaruh secara signifikan terhadap ketepatan pemberian opini. Variabel kecerdasan emosional ditentukan dengan melihat nilai signifikansi di tabel Coefficients yaitu dengan nilai 0,276 lebih besar dibanding dengan 0,05 ini berarti kecerdasan emosional tidak berpengaruh secara signifikan terhadap ketepatan pemberian opini. Variabel kecerdasan spiritual ditentukan dengan melihat nilai signifikansi di tabel Coefficients yaitu dengan nilai 0,000 lebih kecil dibanding dengan 0,05 berarti kecerdasan spiritual berpengaruh secara signifikan terhadap ketepatan pemberian opini.

4.8 Uji F sebelum MRA

ANOVA ${ }^{\mathrm{a}}$

\begin{tabular}{|rl|r|r|r|r|r|}
\hline \multicolumn{1}{|c|}{} & \multicolumn{1}{c|}{$\begin{array}{c}\text { Sum of } \\
\text { Squares }\end{array}$} & df & Mean Square & \multicolumn{1}{c|}{ F } & \multicolumn{1}{c|}{ Sig. } \\
\hline 1 & Regression & 619,551 & 4 & 154,888 & 75,958 &, $000^{\text {b }}$ \\
& Residual & 67,291 & 33 & 2,039 & & \\
& Total & 686,842 & 37 & & & \\
\hline
\end{tabular}

a. Dependent Variable: Opini

b. Predictors: (Constant), Pengalaman Auditor, Kecerdasan Spiritual, Kecerdasan Emosional, Kecerdasan Intelektual

Berdasarkan hasil uji $\mathrm{F}$ sebelum moderasi didapatkan nilai signifikansi di tabel Coefficients yaitu dengan nilai 0,000 lebih kecil dibanding dengan 0,05 ini berarti kecerdasan intelektual, kecerdasan emosional dan kecerdasan spiritual secara simultan berpengaruh secara signifikan terhadap ketepatan pemberian opini. 


\subsection{Uji Hipotesa Setelah MRA}

Model Summary

\begin{tabular}{|l|r|r|r|c|}
\hline Model & $\mathrm{R}$ & $\mathrm{R}$ Square & $\begin{array}{c}\text { Adjusted R } \\
\text { Square }\end{array}$ & $\begin{array}{c}\text { Std. Error of the } \\
\text { Estimate }\end{array}$ \\
\hline 1 &, $961^{\mathrm{a}}$ &, 923 &, 905 & 1,3297 \\
\hline
\end{tabular}

a. Predictors: (Constant), Moderating 3, Kecerdasan Emosional, Kecerdasan Intelektual, Pengalaman Auditor, Kecerdasan Spiritual, Moderating_2, Moderating_1

Pada tabel 7 Uji Koefesien Determinan setelah moderasi bisa kita lihat nilai Adjust $R$ Square sebesar 0,905 atau dalam presentase sebesar $90,5 \%$ variabel ketepatan pemberian opini audit dapat dijelaskan atau dipengauhi oleh variabel 3 kecerdasan dengan dimoderasi pengalaman auditor, sedangkan sisanya sebesar $9,5 \%$ dijelaskan oleh faktor-faktor lain yang tidak termasuk dalam analisa regresi pada penelitian ini.

Coefficients $^{\mathrm{a}}$

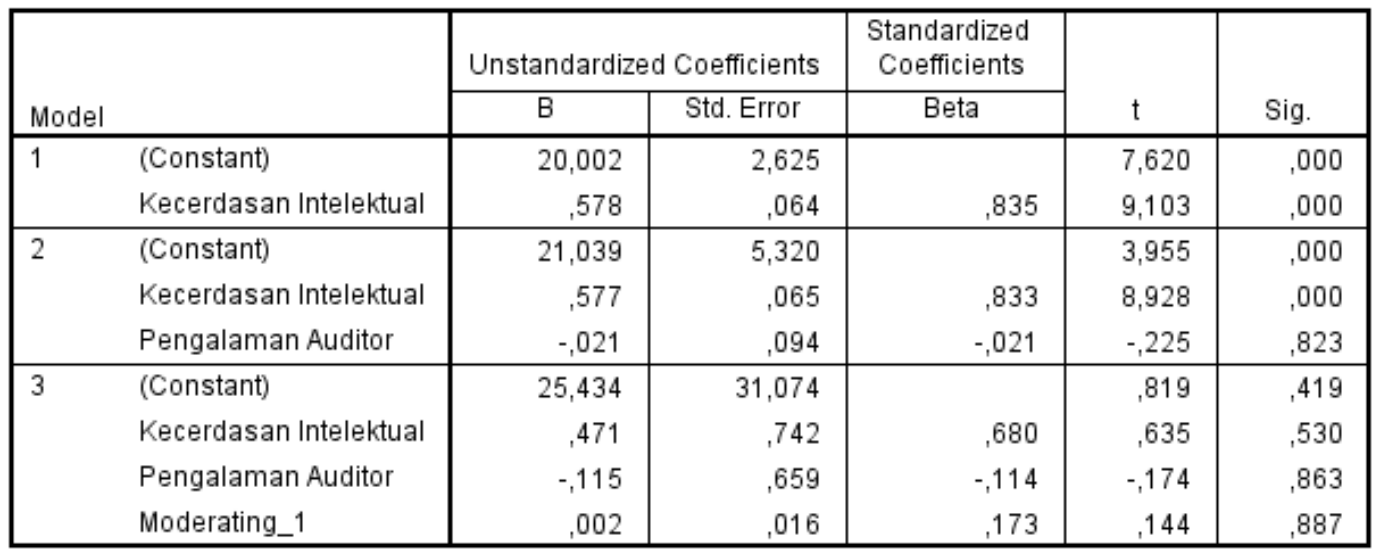

a. Dependent Variable: Opini

Dalam penelitian ini dilakukan uji multiple regresi analisyst (MRA) untuk mengetahui apakah pengalaman memperkuat pengaruh kecerdasan intelektual terhadap ketepatan pemberian opini audit. Berdasarkan Tabel 8 memperoleh hasil bahwa nilai signifikansi kecerdasan intelektual dengan dimoderasi oleh pengalaman lebih besar dari 0,05 yaitu 0,887 . Hal ini menunjukkan bahwa variable moderasi pengalaman memperlemah pengaruh kecerdasan intelektual terhadap ketepatan pemberian opini audit. 
Coefficients $^{\mathrm{a}}$

\begin{tabular}{|c|c|c|c|c|c|c|}
\hline \multirow[b]{2}{*}{ Mode } & & \multicolumn{2}{|c|}{ Unstandardized Coefficients } & \multirow{2}{*}{$\begin{array}{c}\begin{array}{c}\text { Standardized } \\
\text { Coefficients }\end{array} \\
\text { Beta }\end{array}$} & \multirow[b]{2}{*}{$t$} & \multirow[b]{2}{*}{ Sig. } \\
\hline & & $B$ & Std. Error & & & \\
\hline \multirow[t]{2}{*}{1} & (Constant) & 42,239 & 2,746 & & 15,381 &, 000 \\
\hline & Kecerdasan Emosional &, 037 &, 071 &, 087 &, 525 & 603 \\
\hline \multirow[t]{3}{*}{2} & (Constant) & 46,485 & 8,556 & & 5,433 &, 000 \\
\hline & Kecerdasan Emosional &, 034 &, 072 &, 080 &, 477 &, 636 \\
\hline & Pengalaman Auditor &,- 089 &, 169 &,- 088 &,- 525 &, 603 \\
\hline \multirow[t]{4}{*}{3} & (Constant) & $-5,522$ & 29,267 & &,- 189 & 851 \\
\hline & Kecerdasan Emosional & 1,420 &, 751 & 3,318 & 1,890 &, 067 \\
\hline & Pengalaman Auditor & 1,029 &, 625 & 1,023 & 1,646 & 109 \\
\hline & Moderating_2 &,- 030 &, 016 & $-3,354$ & $-1,853$ & 073 \\
\hline
\end{tabular}

a. Dependent Variable: Opini

Dalam penelitian ini dilakukan uji multiple regresi analisyst (MRA) untuk mengetahui apakah pengalaman memperkuat pengaruh kecerdasan emosional terhadap ketepatan pemberian opini audit. Berdasarkan Tabel 8 memperoleh hasil bahwa nilai signifikansi kecerdasan emosional dengan dimoderasi oleh pengalaman lebih besar dari 0,05 yaitu 0,073. Hal ini menunjukkan bahwa variabel moderasi pengalaman memperlemah pengaruh kecerdasan emosional terhadap ketepatan pemberian opini audit.

Coefficients $^{\mathrm{a}}$

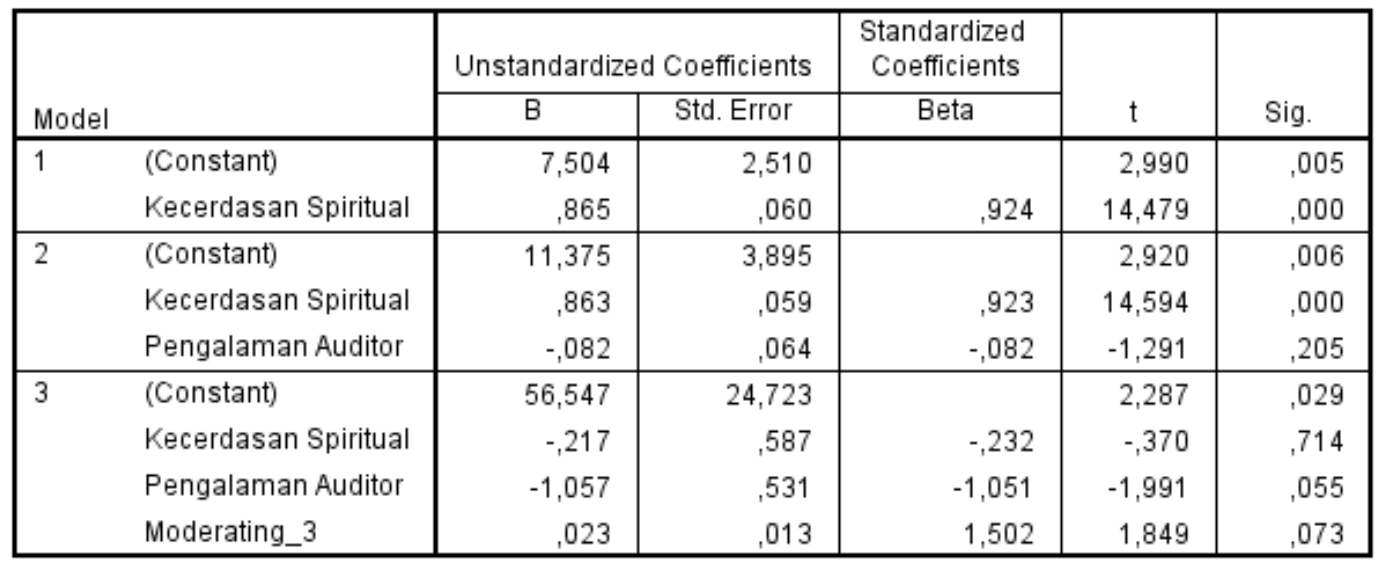

a. Dependent Variable: Opini

Dalam penelitian ini dilakukan uji multiple regresi analisyst (MRA) untuk mengetahui apakah pengalaman memperkuat pengaruh kecerdasan spiritual terhadap ketepatan pemberian opini audit. Berdasarkan Tabel 8 kooefisien memperoleh hasil bahwa nilai signifikansi kecerdasan spiritual dengan dimoderasi oleh pengalaman lebih besar dari 0,05 yaitu 0,073 . Hal ini menunjukkan bahwa variable moderasi pengalaman memperlemah pengaruh kecerdasan spiritual terhadap ketepatan pemberian opini audit. 
Hasil Uji F setelah MRA

\begin{tabular}{|c|c|c|c|c|c|c|}
\hline \multicolumn{7}{|c|}{ ANOVA $^{\mathrm{a}}$} \\
\hline & & Sum of Squares & df & Mean Square & $\mathrm{F}$ & Sig. \\
\hline \multirow{3}{*}{1} & Regression & 633,796 & 7 & 90,542 & 51,206 &, $000^{b}$ \\
\hline & Residual & 53,046 & 30 & 1,768 & & \\
\hline & Total & 686,842 & 37 & & & \\
\hline
\end{tabular}

a. Dependent Variable: Opini

b. Predictors: (Constant), Moderating_3, Kecerdasan Emosional, Kecerdasan Intelektual, Pengalaman Auditor, Kecerdasan Spiritual, Moderating_2, Moderating_1

Berdasarkan hasil uji $\mathrm{F}$ setelah moderasi didapatkan nilai signifikansi di tabel Coefficients yaitu dengan nilai 0,000 lebih kecil dibanding dengan 0,05 ini berarti kecerdasan intelektual, kecerdasan emosional dan kecerdasan spiritual secara simultan bersama-sama berpengaruh secara signifikan terhadap ketepatan pemberian opini dengan dimoderasi pengalaman.

\subsection{Pembahasan}

4.7.1 Pengaruh kecerdasan intelektual terhadap ketepatan pemberian opini audit

Hasil uji parsial kecerdasan intelektual ditentukan dengan melihat nilai signifikansi di tabel Coefficients yaitu dengan nilai 0,005 lebih kecil dibanding dengan 0,05 berarti kecerdasan intelektual berpengaruh secara signifikan terhadap ketepatan pemberian opini. Jika seorang auditor memiliki kecerdasan intelektual yang baik maka akan mampu memahami dan mengaplikasikan wawasan pengetahuan yang diperoleh untuk memberikan opini audit yang tepat. Hasil penelitian ini mendukung penelitian Silvia Hellena (2015) dan Aprilian Orgawan (2015) yang menyatakan bahwa kecerdasan intelektual memiliki pengaruh yang signifikan terhadap ketepatan pemberian opini auditor.

4.7.2 Pengaruh kecerdasan emosional terhadap ketepatan pemberian opini audit

Variabel kecerdasan emosional ditentukan dengan melihat nilai signifikansi di tabel Coefficients yaitu dengan nilai 0,276 lebih besar dibanding dengan 0,05 berarti kecerdasan emosional tidak berpengaruh secara signifikan terhadap ketepatan pemberian opini. Kecakapan emosi dan keyakinan emosi menimbulkan rasa empati dengan hasil yang subyektif, sehingga seorang auditor dalam mengambil suatu keputusan salah satunya keputusan dalam pemberian opini audit yang lebih pada adanya rasa empati. Penelitian ini sesuai dengan penelitian mardiayah dan effendi (2017) dan nurul husna (2019).

4.7.3 Pengaruh kecerdasan spiritual terhadap ketepatan pemberian opini audit

Variabel kecerdasan spiritual ditentukan dengan melihat nilai signifikansi di tabel Coefficients yaitu dengan nilai 0,000 lebih kecil dibanding dengan 0,05 berarti kecerdasan spiritual berpengaruh secara signifikan terhadap ketepatan pemberian opini. Dengan Kecerdasan spiritual yang baik auditor dapat menyelaraskan perasaan, emosional dan otak untuk mengekspresikan dan memberi makna pada setiap tindakannya sehingga mendukung ketepatan pemberian opini. Penelitian ini mendukung penelitian yang dilakukan oleh Silvia Hellena (2015) dan Putu Candra Mitha Swari (2013).

4.7.4 Pengaruh kecerdasan intelektual terhadap ketepatan pemberian opini audit dengan dimoderasi pengalaman

Hasil uji multiple regresi analisyst (MRA) menunjukkan hasil bahwa nilai signifikansi kecerdasan intelektual dengan dimoderasi oleh pengalaman lebih besar dari 0,05 yaitu 0,887. Hal ini berarti bahwa variable moderasi pengalaman tidak mampu memperkuat pengaruh variable kecerdasan intelektual terhadap ketepatan pemberian opini. 
Dengan memiliki kecerdasan intelektual seorang auditor mampu memahami dan menggunakan pengetahuan dalam bidang akuntansi dan auditing tidak terbatas berapa lama audtor bekerja sehingga tidak hanya membutuhkan pengalaman saja melainkan sikap profesionalisml dan independensi turut menentukan dalam memberikan opini audit yang tepat.

4.7.5 Pengaruh kecerdasan emosional terhadap ketepatan pemberian opini audit dengan dimoderasi pengalaman

Hasil uji multiple regresi analisyst (MRA) menunjukkan hasil bahwa nilai signifikansi kecerdasan emosional dengan dimoderasi oleh pengalaman lebih besar dari 0,05 yaitu 0,073. Hal ini berarti bahwa variable moderasi pengalaman tidak mampu memperkuat pengaruh variable kecerdasan emosional terhadap ketepatan pemberian opini. Mengelola emosi dan suasana hati dengan kecerdasan emosional yang baik membantu auditor pada saat audit tidak hanya dibatasi berapa banyak penugasan yang pernah dilakukan sehingga tidak hanya membutuhkan pengalaman saja tetapi keahlian auditor dan obyektivitas auditor membantu dalam ketepatan pemberian opini audit.

4.7.6 Pengaruh kecerdasan spiritual terhadap ketepatan pemberian opini audit dengan dimoderasi pengalaman

Hasil uji multiple regresi analisyst (MRA) menunjukkan hasil bahwa nilai signifikansi kecerdasan spiritual dengan dimoderasi oleh pengalaman lebih besar dari 0,05 yaitu 0,073. Hal ini berarti bahwa variable moderasi pengalaman tidak mampu memperkuat pengaruh variable kecerdasan spiritual terhadap ketepatan pemberian opini. Setiap auditor dituntut bertindak atau berperilaku secara etis dalam profesinya dan organisasi dengan kecerdasan spiritual yang tinggi, dan tidak hanya melihat pada lama bekerja atau berapa jumlah penugasan auditor melainkan didukung etika dan kompetensi dalam memberikan opini audit yang tepat.

Kesimpulan dan Saran

Kesimpulan

Berdasarkan pada data dan hasil dari penelitian yang telah diuraikan sebelumnya, maka dapat ditarik kesimpulan sebagai berikut :

1. Kecerdasan intelektual mempunyai nilai signifikansi lebih kecil dibanding dengan 0,05 yaitu $0,005<0,05$ sehingga kecerdasan intelektual berpengaruh secara signifikan terhadap ketepatan pemberian opini. Penelitian ini mendukung penelitian yang dilakukan sebelumnya oleh Silvia Hellena (2015) dan Aprilian Orgawan (2015).

2. Kecerdasan intelektual mempunyai nilai signifikansi lebih kecil dibanding dengan 0,05 yaitu $0,005<0,05$ sehingga kecerdasan intelektual berpengaruh secara signifikan terhadap ketepatan pemberian opini. Penelitian ini mendukung penelitian yang dilakukan sebelumnya oleh Silvia Hellena (2015) dan Aprilian Orgawan (2015).

3. Kecerdasan intelektual mempunyai nilai signifikansi lebih kecil dibanding dengan 0,05 yaitu $0,005<0,05$ sehingga kecerdasan intelektual berpengaruh secara signifikan terhadap ketepatan pemberian opini. Penelitian ini mendukung penelitian yang dilakukan sebelumnya oleh Silvia Hellena (2015) dan Aprilian Orgawan (2015).

4. Kecerdasan intelektual mempunyai nilai signifikansi lebih kecil dibanding dengan 0,05 yaitu $0,005>0,887$ sehingga pengalaman memperlemah pengaruh kecerdasan intelektual terhadap ketepatan pemberian opini.

5. Kecerdasan intelektual mempunyai nilai signifikansi lebih kecil dibanding dengan 0,05 yaitu $0,005>0,073$ sehingga pengalaman memperlemah pengaruh kecerdasan intelektual berpengaruh terhadap ketepatan pemberian opini.

6. Kecerdasan intelektual mempunyai nilai signifikansi lebih kecil dibanding dengan 0,05 yaitu 0,005 > 0,073 sehingga pengalaman memperlemah pengaruh kecerdasan intelektual terhadap ketepatan pemberian opini. 


\section{Saran}

Untuk penelitian yang akan dating, peneliti memberikan masukan sebagai berikut :

1. Penelitian selanjutnya dapat menambah variabel-variabel yang lebih berpengaruh terhadap ketepatan pemberian opini. Sebagai contoh keahlian, profesionalisme dan etika profesi.

2. Penelitian selanjutnya mampu menggunakan variable moderasi yang lain, sehingga memberikan hasil memperkuat pengaruh variable independen terhadap dependen.

3. Diharapkan dapat memperluas wilayah penelitian (populasi) untuk mendapatkan responden yang lebih banyak.

4. Tidak hanya menggunakan data yang berasal dari survei melalui kuisioner. Sebaiknya digunakan juga metode wawancara agar dapat mendukung hasil yang diperoleh melalui metode kuisioner.

\section{DAFTAR PUSTAKA}

Agoes, Sukrisno. 2013. Auditing (Pemeriksaan Akuntan) Oleh Kantor Akuntan Publik. Jilid I. Edisi Ketiga. Jakarta: Lembaga Penerbit Fakultas Ekonomi Universitas Indonesia.

Arens, Alvin A, Randal J. Elder, Mark S. Beasley. 2010. Auditing and Jasa Assurance : Pendekatan Terintegrasi. Jakarta.

Choiriah, Anis. 2013. Pengaruh Kecerdasan Emosional, Kecerdasan Intelektual, Kecerdasan Spiritual dan Etika Profesi terhadap Kinerja Auditor dalam Akuntan Publik.

Ghozali, Imam. 2016. Aplikasi Analisis Multivariate. IBM SPSS Statistiscs 23. Edisi Kedelapan : Badan Penerbit Universitas Diponegoro Semarang

Halim, Abdul 2015. Auditing Dasar- Dasar Audit Laporan Keuangan. Jilid 1 Edisi kelima. Sekolah Tinggi Ilmu Manajemen YKPN

Hellena, Silvia. 2015. Pengaruh Etika Profesi, Independensi, Kecerdasan Intelektual, Kecerdasan Emosional dan Kecerdasan Spiritual terhadap Ketepatan Pemberian Opini Auditor.

Institut Akuntan Publik (IAP) 2015. Standar Profesi Akuntan Publik. Jakarta. Salemba Empat

Nurul Husna, Asma. 2017. Pengaruh Etika Profesi dan Kecerdasan Emosional Dalam Pengambilan Keputusan Bagi Auditor PAda Kantor Akuntan Publik di Kota Medan.

Prasetya, Ari. 2013. Pengaruh Independensi, Profesionalisme dan Pengalaman Auditor terhadap Prediktor Ketepatan Pemberian Opini Akuntan Publik.

Rachmi, Filia. 2010. Pengaruh Kecerdasan Emosional, Kecerdasan Spiritual dan Perilaku Belajar terhadap Pemahaman Akuntansi. Semarang, Jurnal Pendidikan Akuntansi.

Ranoel, Orgawan Aprilian. 2015. Pengaruh Etika Profesi, Kecerdasan Intelektual, Kecerdasan Emosional dan Kecerdasan Spiritual terhadap Opini Auditor.

Rubiyanto, Eko. 2010. Pengaruh Kecerdasan Intelektual, Kecerdasan Emosional dan Kecerdasan Spiritual terhadap Etika Profesi Auditor. Skripsi Sarjana pada Jurusan Akuntansi pada Fakultas Ekonomi Universitas Udayana.

Sandika, Henda. 2006. Pengaruh Pelaksanaan Etika Profesi dan Kecerdasan Emosional terhadap Pengambilan Keputusan Opini Audit bagi Auditor.

Sukmawati, Ni Luh Gede. 2014. Pengaruh Etika Profesi, Kecerdasan Intelektual, Kecerdasan Emosional dan Kecerdasan Spiritual terhadap Opini Auditor.

Wijayanti, Gersontan lewi. 2012. Peran Kecerdasan Emosional dan Kecerdasan Spiritual dalam Meningkatkan Kinerja Auditor. Jurnal Ilmiah Mahasiswa Akuntansi.

Yulfa, Zailia. 2013. Pengaruh Etika, Profesionalisme dan Pengalaman Audit terhadap Ketepatan Pemberian Opini Akuntan Publik. 